\title{
Megachurches as Educational Institutions
}

\author{
MarkJ. Cartledge
}

\section{Introduction}

The aim of this chapter is to explore the notion that megachurches function as educational institutions for a sector of contemporary Christianity. This sector is largely, if not exclusively, represented by Pentecostal and Charismatic traditions, although there are Evangelical examples as well. For the purposes of this exercise, the chapter will focus on this family of the Christian tradition, which is mostly represented by Independent churches, although it can be found in classical Pentecostalism and denominational Charismatic and Evangelical churches around the world. Given the limitations of space, an exhaustive account cannot be offered. Instead, the intention is to elucidate the significant features of these churches and to reflect on them in the light of the literature in order to offer some evaluation and suggestions for future trajectories.

Before proceeding further, a couple of key terms need to be defined. First, by 'education' is meant the overall process and context for individual and corporate learning. This education may be focused around the development of faith understanding and practices in order to fulfil the vision of what it means to be a Christian within the megachurch setting. But it may also include aspects of a more general nature, most often associated with human flourishing, character and skills development for the benefit of the individual, family or community. Therefore, a broad understanding of education will be taken and it will not be limited to theological cognition and articulation. Second, by 'institution' is meant the organisational context, structure, processes and practices, within which learning occurs and by means of which members affiliated with the institution both contribute to and benefit from the association. In effect, this study discusses church congregations as institutions and the examples used will illustrate educational features from the different sectors of institutional life.

In order to fulfil the aim of the study, this chapter will first offer a general overview of the nature of Christian congregations as sites of educational processes. This is because megachurches are, in effect, subsets of wider congregational level education, as well as transcending this model by means of their 
more extended multi-congregational, multi-site and network arrangements. Once this context has been established, the study continues by describing the features which often characterise megachurches as educational institutions. This is the heart of the chapter and it is illustrated by examples for the literature in the field as well as megachurch websites, which are crucial ways of gaining initial access to their ethos and ideology. The chapter closes with a summary of the general characteristics of these educational institutions before offering an evaluation, as well as suggesting possible future trajectories for them. A conclusion places this essay in the context of the megachurch literature and suggests ways in which it is significant for scholarship.

\section{$2 \quad$ Congregational Education}

In general, it could be said that churches and congregations function as sites of educational processes (Everist 2002). This is because central practices enacted by groups of people meeting for congregational life provide structures and opportunity for learning to occur: they participate in social learning experiences (Hermans 2003: 275). Of course, it would be a mistake to assume that congregations are primarily like schools and colleges. Their main aim is not to produce citizens for earthly employment; nevertheless, they do contribute to the equipping of the saints for gainful activity, even as their focus is the formation of disciples who follow Jesus Christ and worship God. In other words, while their primary concern is the worship of God and the mission of the church, often defined in terms of evangelism and social action, they also shape individuals to be particular kinds of people that represent their faith in wider society (see the discussion of congregations as institutions by Jordan 2005). Congregations shape their members by what is made explicit, what is signalled implicitly and even by what is obviously avoided (sometimes referred to as the null curriculum) (Hinton 2009, 2011; Pazmiño 2008: 243-248). Given this background, a number of distinct features of congregational learning may be identified.

\subsection{Education in a Congregational Setting}

It could be argued that at the heart of congregational learning is the process of socialisation. Socialisation refers to the means by which individuals take on board the beliefs, values and practices of a particular community or society such that they move from the outside to the inside of that community (Fulcher and Scott 2003). In terms of society in general, primary socialisation is mediated by means of parents and families, schools and children's organisations, 
clubs and subsequently institutions of Higher Education. Congregations are very much part of these socialisation structures because they provide resources that both support the values of wider society as well as challenging them from time to time. Chiefly, though, they are the primary means by which individuals come into contact with the Christian faith via a significant other (family member, friend, or pastor) and begin to explore the Christian faith as a viable alternative to other religions or no religious affiliation. Very often, children simply grow up within the faith, in which case the relationship between the family and the congregational socialisation of faith is very close indeed. At the heart of the socialisation process is the weekly act of congregational worship: faith is inculcated and enacted in the worshipping practices of the congregation (Chaves 2004: 182-201). Faith is learned, practised, felt, embodied and performed not just individually but also collectively. This activity cannot be underestimated as the engine of institutional learning for congregations.

Congregations provide opportunities to acquire knowledge of the faith by means of specific learning practices. For example, it was common in the Church of England and other mainline denominations to prepare young people for the rite of confirmation (at which young people affirmed the faith for themselves). In the preparatory confirmation classes, a pastor or priest explained key doctrinal points as well the nature of the Sunday liturgy. Alongside these classes, specific age-focused learning opportunities, such as Bible studies or discussion groups are provided that enable the young people to explore the meaning of faith, not just in general terms but also in specific ways as they seek to understand how religious commitments affect them personally. The growing up in the faith is an important aspect of congregational education and a considerable amount of energy and resources are channelled towards children and young people.

Increasingly, congregations are realising that just as they need to provide opportunities and resources for children and young people, so they need to attend to other groups, so that the growth in knowledge and understanding of the faith can be seen across the different generations in the church, including adults (Isaac 2012: 86). This means that while Sunday morning worship is often mixed generationally, there are now mid-week opportunities for men, women, younger and older people, as well as mothers and toddlers. The range of learning activities will vary according to the resources and culture of each individual church community. Nevertheless, there is a growing awareness that spiritual maturity is something that develops over time and certain opportunities facilitate this maturity, thus providing leaders for the current congregation and its future. For some church leaders, this means exposing congregants to critical biblical scholarship as part of the learning context (Mercer 2006: 174). 
It is always the case that congregations are embedded in and function in relation to wider society. It cannot be any other way. This means that they draw their members from this wider society and they also contribute to it in multiple ways. Congregational members live, work, socialise and engage in multiple activities as part of this wider society. Very often, this is based at the local level in which these congregations are geographically situated. They provide various resources that impact communities in positive ways. Congregations also belong in many cases to denominations, and these denominations produce resources and commentaries on public issues in society. Sometimes they come into direct conflict with national and local government policy on matters of social and political issues. In other cases, they appear to reflect direct sympathies with political parties and policies. In many cases these congregations and denominations are part of networks and groups that work together to foster greater cooperation and the sharing of ideas, projects, resources and expertise. At times, there can be tensions with wider society, as values once aligned between the two become strained and fault lines emerge both between church groups and wider society, as well as within and among church groups on precisely the same issues (for example, the changing values and attitudes towards sexuality and social institutions such as marriage).

\subsection{Congregations as Institutions}

As institutions, congregations provide many different kinds of educational opportunities. In a lot of cases what is offered would not be classified as 'formal' education because there is no accredited qualification provided at the end of a given course of instruction. In some cases, there are arrangements with universities and colleges, with congregations providing learning hubs as part of a network. This educational trajectory starts informally, develops by means of networking, then conferences and subsequently formal arrangements with a local Higher Education institution are established. Based on information gleaned in 2000, Thumma and Travis observe that approximately 30 percent of US megachurches sponsor some kind of training or educational arrangement, whether formally accredited or not (2007:131). Congregations often function as part of a wider parachurch network and the academic expertise for this learning is provided elsewhere. For the most part, what is offered by congregations is less formal education, although it is mediated through the teaching offices of the church leaders and staff. In many cases, these are people who have been trained in theology, having some recognised qualification, such as degrees in theology from universities as part of their ministerial training. They use their training to provide teaching through sermons, very often constructed as part of a series and dealing with everyday issues by bringing the Bible into conversation 
with them. The sermon probably stands out as the most important teaching vehicle that the congregation has in the formation of its members in their Christian discipleship.

This main vehicle of learning is supplemented by other means, for example small group meetings, which include Bible studies of various kinds. Sometimes there are specific study groups, perhaps linked to a season of reflection such as Lent or Advent. In some cases, these seasonal activities provide an opportunity to collaborate with other churches in the area as part of an ecumenical arrangement. These group activities thus offer a peer-learning context, which supports the existing learning opportunities through Sunday worship. There are also courses directed at specific groups of people at certain life stages, such as marriage preparation courses, parenting courses, workplace spirituality courses and bereavement courses. Some churches seek to invest in the next generation of their members by delivering courses to grow new leaders and perhaps nurture vocations into full-time ministry. As part of this kind of learning activity mentors and prayer partners are provided for a period of time, which allows individuals to obtain what appears to be similar to a personal tutor in the spiritual life.

\section{3}

\section{Education and Megachurches}

Given this general context to congregations as institutions, the precise nature of megachurches as educational institutions will be considered in this section. In many ways, the picture is somewhat similar to the one already painted above, but megachurches also offer features that are distinct, given their character, and these are important to note. Of course, megachurches vary enormously, and a certain liberty is expressed in the description that follows in the sense that generalisations need to be made for the purposes of this kind of discussion. Nevertheless, examples of practices are based in the literature of megachurches from around the world. [Given the discussions of the nature of megachurches and how they have been categorised (e.g. Thumma and Travis 2007), a description of them will not be attempted here.]

\subsection{Congregational Education}

To attend a megachurch Sunday by Sunday is to be part of a congregation of hundreds, if not thousands, depending on the church and its location. Due to the sheer scale of the operation, for many people it feels as though they are attending a conference, a major event or a concert. But it is none of these 
things; it is a regular weekly event, whether it is held on a Saturday night or a Sunday morning. Therefore, given the numbers attending this kind of weekly worship, the first thing to observe is that learners, at least at the weekly Sunday level, are part of the crowd and a very large crowd at that. They are often herded by ushers into a very large auditorium, which may or may not be a dedicated church building. This means that the physical context for the main learning experience can communicate the everyday, the utilitarian and the idea that this is an experience of learning for the masses. The experience of worship becomes, in effect, an educational tool, which is initiated the moment a person enters into the church building (Barnes 2010: 39, 61), communicating aesthetic values that are learned over time (Klaver 2015).

The faith is communicated, taught and learned via a variety of means, including the prayers that are prayed, the songs that are sung, the sermon that is preached and even the notices that are announced, as well as any socialising that occurs before or after the service in the cafeteria or coffee areas contained within the buildings. In many megachurches, there is a shop that sells books and material that supports the ideology of the particular community, so the preacher's sermons are edited and published as books, which the members read and discuss among themselves.

The way in which leaders from the platform articulate their faith and communicate it in public prayer is one of the aspects that is absorbed by the congregations. Very often in megachurches, the person leading the opening and closing prayers will pray in an extempore fashion, using particular Christian jargon and code words that signal theological commitments and specific understandings. For example, they might reflect an understanding related to the 'prosperity gospel' and the fact that God provides for the material needs of his children not just their spiritual ones. This discourse is therefore modelled by the leader and promoted consistently through repetition. This kind of understanding is absorbed by the members over time, as part of the overall socialisation process, such that new members begin to use the same language, understand the same concepts and practise the same kind of speech themselves. Thus, they move from the outside of the language game to the inside of it. Quite often megachurch leaders think in terms of attendees as belonging to different commitment levels, with core members at the centre (about 20 percent of weekly attendees) and visitors and spectators at the periphery (about 10 percent of weekly attendees). One of the goals of megachurches is the mobilisation of as many people as possible for the sake of their mission and this means socialising people via learning structures and processes towards being core committed members, or moderately committed members (about 
40 percent of weekly attendees) which means that the overall educational environment is central to the life of a megachurch (Thumma and Travis 2007: 102-107).

Music is important to Christianity and it has a rich musical history that reflects the varied times and places of its practice around the world. Music in Pentecostal and Charismatic Christianity, among which the megachurches of the world tend to be located, has elevated the musical component to a significant place in the overall liturgical process. In most of these churches there will be a praise and worship period when the congregation is led in a sustained act of singing three to six or more songs. These songs are selected according to the worship/band leader's interests or according to the theme of the Bible passage set for the service. The words of the songs are sung repetitively, so that while they appear on big screens in front of the congregation they are easily memorised and internalised. The theological content of these songs will tend to be on the light side, with a strong affective component. It appeals less to the intellect and more to the affections, allowing congregants to express their heart-felt instincts towards God in praise and adoration, as well as feeling connected to the community of the church (Wade and Hynes 2013). This means that what is learned theologically via the songs is also connected at an emotional level, which supports the ideas that the most profound learning is not simply cognitive but also emotional and volitional. People choose to sing these songs with others and by doing so they allow themselves to be socialised into a set of beliefs about God, the world and themselves.

The sermon in megachurches is often a slick message, simple, very well crafted using Bible verses as pegs from which to jump from idea to idea and providing a practical and highly motivational message. Different examples can be seen in the sermons of Joel Osteen (Carney 2012; Sinitiere 2015), T.D. Jakes and Creflo Dollar (Hinton 2011). The styles of preaching will vary according to culture and context, but it has been suggested that they do not represent the classical homiletical styles of older traditions (Thumma and Travis 2007: 65). Nevertheless, the quality of presentation can be very high, often with polished PowerPoint slides and images to reinforce the key points of the message. The congregation is treated to a skilled rhetorician, who has tapped into the desires and aspirations of those individuals present and seeks to communicate in a way that is accessible and relevant, while often avoiding controversial social and political issues (Vermeer 2015). Some megachurches, designated the 'Charismatic/Pastor-focused' churches founded by an entrepreneur, or perhaps a socalled 'pastorpreneur', often focus on the preaching and teaching of the founding pastor as the most important educational focal point (Thumma and Travi, 2007:37-38). Even when this is not the case, the sermon is still the key learning 
experience for many megachurch members and it would be easy to think that such a learning experience is a rather passive one. It could be assumed that listeners simply take what they hear: believing it and receiving it. This may indeed be the case in some contexts. But in others, members of the church follow along by looking up Bible texts in their own Bibles or by using phone apps. They are assimilating ideas critically, even when this appears not to be the case. Thus, ideas from the preacher are actively assessed at the individual level during the service and perhaps discussed with friends after the service in social settings. One of the key criteria for assessment is whether the preacher bases his or her teaching in the Bible itself, hence very often there is a proliferation of biblical texts in use, often cited in a proof-text fashion in order to demonstrate that the preacher is in fact preaching from the 'Word of God'. But again, it is worth noting that the theological discourse communicated via sermons has a profound affect on the learning of congregations as they absorb key ideas through such discourse. This is noted by Barnes, when she states: "I contend that in the Black megachurch tradition, worship represents a time of collective instruction where a captive audience can be socialised toward the specific vision and theology of a charismatic senior pastor. Not only do congregants 'see' physical examples of success on the church grounds, they are taught that God can make similar successes possible to the faithful and that they should expect them"' (2010: 63).

It is easy to overlook the apparent minor points of the service as learning experiences, for example the announcements and the collection. In many megachurches, the weekly notices are communicated via a short video, which is played during a dedicated slot in the service. This short video is probably the nearest thing to the branding tool of the website for communicating events and activities and for packaging the life of the church for the outside viewer. So, while this event of giving inside information on the life of the church is primarily aimed at members, it is also outward facing and so intended to be attractive for would-be members. This means that while the discourse connects with the internal narrative it has an accessible quality. Thus, again, it models how to communicate the faith of the church in a manner that is engaging and with high quality media.

In this section, it is also worth noting how the church expresses itself in terms of the giving of money. Almost every congregation, let alone a megachurch congregation, has an act of giving as part of the liturgy of worship and, in this regard, megachurches are no different to any other kind of church community. However, because the numbers attending are so large and because the 'prosperity gospel' has often been associated with megachurches (TuckerWorgs 2011: 87-102), it is worth noting that the language around money is also 
transmitted and learned from the ways in which money is collected and received. It comes as no surprise to find that there appears to be some association between prosperity rhetoric and the rite of the collection bag or bucket. However, a note of caution must be struck here because it has been suggested that not as many megachurches espouse a 'prosperity gospel' as has been imagined and very often 'Seeker-sensitive' megachurches will refrain from speaking about money at all (cf. Bowler 2013; Thumma and Travis 2007: 114-115). This means that attitudes towards money can be reinforced, challenged and even occluded by the practices of money collection.

\subsection{Learning through Small Groups and 'Courses'}

Many megachurches are regarded as 'programme-based'. That is, they provide a great array of different programmes and 'courses' that cater to the interests and needs of their membership. Megachurches 'intentionally structure multiple ways for people to interact and form social ties', such that the use of small groups is now regarded as a universal practice among megachurches (Thumma and Travis 2007: 48; von der Ruhr and Daniels 2012). Many of these small groups are constituted for the purpose of Christian education as part of a 'course' or a 'class' and regarded as central to their vision of spiritual formation. By a 'course', I mean a series of meetings aimed at informing members and visitors about a body of knowledge (although not called that) and assisting them to process that body of knowledge via learning strategies such as talks, discussions, question and answer sessions and homework of some kind. Bible classes have been identified as the primary means of Christian education in the socalled Old Line/Programme-Based churches (Kay 2004: 235; Thumma and Travis 2007: 3). Many of these courses include at their heart exercises that enable people to study the Bible, suitably mediated through a particular lens that is acceptable to the doctrinal stance of the church leadership.

In many cases, there is a programme-based process evangelism course, that explores the basis of the Christian faith, builds relationships and integrates enquirers into the fellowship of the church. Very often courses are supported by mentors who help the integration and socialisation of new members (Thumma and Travis 2007:49). Some courses help individuals to navigate their way through the complexities of life. So, as noted above, life seasons are often attended to, for example preparation for engagement and marriage, parenting and life changes such as bereavement and retirement. Other courses are therapy-based, such as addiction, eating disorders and mental health support through groups. Further courses are intended to support career development, for example advising on how to get into the best universities and colleges, or how to integrate the Christian faith into working practices, as well as finance 
management and the avoidance of debt. Added to these educational courses, there are more leisure-based courses similar to what one might find in a community centre, such as art, exercise and sports classes of various kinds. The so-called 'New Wave/Re-envisioned' type of megachurch has rejected the reductionism of the 'Seeker-sensitive' approach and has embraced more traditional forms of spirituality, which include classes on spiritual journaling, fasting and prayer, as well as contemplative meditation practices (Thumma and Travis 2007:41).

These courses attempt to bring a Christian perspective on the subject under discussion. So, for example, while money may be discussed in a practical manner, there may well be a discussion of what the Bible has to say on the subject, its stewardship and the dangers of falling into debt. While these types of courses are constructed for insiders, there is always the possibility that visitors may be taking them for their own interest. Thus, these courses may provide a dual role of skills development as well as building relationships through which the Christian message may be shared, and the outsiders evangelised. For many megachurches, this is where there is an integration of what is offered for their membership with an opportunity or entry point for would-be members to experience what is on offer; thus education and evangelism intersect. Megachurches tend to see all events as potentially evangelistic opportunities and, while there is often sensitivity to outsiders, there can be a boldness in sharing the Christian message when this is viewed as appropriate. The 'Seekersensitive' megachurches attempt to make the whole of their culture as accessible as possible for enquirers and this can have a major influence on the nature of language, the use of symbols and a toning down of distinctly Christian practices, for example the frequency and location of the sacraments, which can be minimised for the sake of evangelism (Thumma and Travis 2007:39).

It was stated above that only a minority of megachurches have formal educational programmes as part of their provision. (This is indeed the case, although I shall note the Black megachurch school provision below as part of their engagement with local social need.) Nevertheless, there are examples of megachurches participating in formal Higher Education provision. There are two obvious examples that are identifiable from research.

First, Hillsong Church, Sydney, Australia provides an on-campus vocationallevel diploma in Christian ministry, focusing especially on leadership and theology, that attracts approximately 2,00o students from around the world at any given time (Burns 2017: 273). This is located at their two Sydney campuses and the students meet daily for worship and classes from lecturers who are qualified at least to the Master's level, with some having Doctoral qualifications. The students are taught theology and ministry in an integrated and confessional 
manner that interfaces with Pentecostal and Charismatic scholarship. More recently, a partnership with the Pentecostal College, Alphacrucis, has opened up the delivery of BA and MA programmes in Christian theology and ministry. All of these courses are fully accredited through the Australian educational system. The educational approach of the College is to instil the culture of the Church into the programmes of the College, by which is meant the core values of the Church since the students are immersed in both the College and the Church during their studies (Soon 2017: 111). The educational processes of the College thus reinforce and support the distinctive theological identity of the Church in the context of wider Pentecostal and Charismatic expressions of Christianity with which Hillsong is connected.

Second, Holy Trinity Church Brompton [нтв] has been known to support theological education via its St Paul's Theological Centre [https://sptc.htb.org/ about], which is affiliated with St Milletus College [https://www.stmellitus. org/history]. This College prepares women and men for ordination in the Church of England and it is sponsored by the Diocese of London, being located in Courtfield Gardens, Earlscourt. This church is one of four congregations that form the hub of нтв and it doubles as an educational and worship site. This particular church is known for being more intellectual in its offering on a Sunday and so attracts people who desire this kind of church community. Additionally, нтв has been known to sponsor theological conferences. For example, in 2010 it hosted the 'Holy Spirit in the World Today' conference, which attracted speakers such as Jürgen Moltmann, Rowan Williams, Miroslav Volf and David Ford. Thus, нтв provides a high-level opportunity for theological exchange and interaction, which is unusual for megachurches in general (Cartledge et al, 2019: 121-130).

\subsection{Learning through Service Opportunities}

One of the great advantages of participating in the life of a megachurch is the exceptional array of activities that one may be drawn into and to which one may make a contribution. Very often these service opportunities are linked to participation as a member of a small group of some kind (Thumma and Travis 2007: 87). As part of the range of activities is the opportunity it affords members to learn new skills. A number of new skills stand out as important for the life of the church, but which are eminently transferable to other spheres of life, thus enhancing the versatility of members within the church but also outside of it, even contributing to their employability in more general terms. A number of examples can be identified, but I shall simply note three at this juncture: public communication skills, organisational knowledge and skills and interpersonal skills. In many cases, it is through these opportunities that pastors are 
active in their attempt to train the next generation of lay and ordained leaders (Barnes 2010: 87).

An important aspect of any church is the ability of its leaders to communicate verbally. This is especially important in Protestant churches, where the proclamation of the Christian message via the pulpit can be prized as a sign of one's calling to the pastorate. In the megachurch setting, pastors who have the platform must be able to communicate to thousands of people simultaneously, because sermons can be 'live streamed' to different campuses of the same church. The preacher may be speaking to two or three thousand people sat in front of him or her, but there are many more watching via relay screens at other locations. And this need to be able to communicate effectively via public speaking is also transferred to smaller gatherings, whether these are smaller worship events for children or youth, or evangelistic events, or social engagement events. There is a premium on clear and effective communication and this is modelled and encouraged by those leadings small groups or specific ministries. Volunteers in these ministries can find themselves called upon to speak in front of others quite quickly and over time develop confidence and skills in communication that would take considerable time to develop otherwise. Once attained, this basic ability to speak publicly and address a group of people can be transferred to other contexts whether committee meetings, work-based conferences, other voluntary sector opportunities, or the political sphere and even the media. Indeed, many megachurches have developed their own TV networks and the most gifted may find themselves developing a ministry via these opportunities that would not have been possible had they not been given initial learning opportunities on a smaller scale.

Another area of skills training through ministry opportunities is the organisational side of megachurch life. Quite clearly, for a megachurch to function in any meaningful sense there needs to be people with administrative acumen able to work alongside pastors and leaders to organise things. These organisations often have huge budgets given their numbers and so financial planning and management are essential. They also have significant buildings to use and maintain, as well as the technology that accompanies contemporary worship services with musical equipment, computers, projectors, screens and lights. Many of these churches organise huge annual and seasonal events that attract thousands of people and require long term planning and periods of intense organisation. They also use cutting-edge technology, especially in the use of the media, and individuals can acquire expertise often lacking elsewhere in the voluntary sector. Many of the Black megachurches provide material for recognised TV channels (Tucker-Worgs 2011: 22). In order for the life of these megachurches to function, they require gifted and committed people. This 
also gives opportunity for members to volunteer in these areas, provide personnel support for tasks but also to learn through their service in a variety of organisational roles. These organisational service roles provide many different experiences of gaining knowledge and skills of how to plan and manage the life of a large institution. Once again, over time, this knowledge base can become internalised to such a degree that it is transferable to other spheres of working life.

One cannot be involved in congregational life at any level before it is realised that fundamentally it is about people. Of course, Christianity claims and functions on the assumption that there is an interaction with God, but from a sociological perspective we are dealing with people (even if we assume theologically that the Holy Spirit is mediated via people). Learning to work with people and with all kinds of people is something that is acquired over time. Once again, it can be noted how megachurches through their ministries provide opportunities to work with a variety of people, from children and young adults to the range of congregational members, to those who are on the margins of society, such as the homeless, the unemployed, migrants and refugees. It is easy to miss the fact that with the huge numbers attending these churches there are learning opportunities all over the institution when viewed in terms of working with people. Most of the social outreach activities are staffed by volunteers and they obtain challenging and valuable experience regarding how to work alongside others in the provision of a service as part of a team, as well as direct engagement with service users. These people may be struggling with mental and physical health issues as well as social issues, so the experience gained from this interaction, especially when sustained over a period of time, can be hugely formational in terms of character and virtue. It is not just about what people know and what skills they gain, but also what kinds of people they become. Megachurches provide service opportunities that help shape individuals and communities. This learning dimension is often lost in the analysis of megachurches but it is hugely important for them and for us in our assessment of their contribution.

\subsection{Learning as a Community in Relation to Culture and Society}

One of the main criticisms of megachurches, especially from the sociological literature that has been produced from the analysis of the American megachurch scene, is that megachurches simply reflect American culture. The main criticism is that they are consumerist in ethos and treat attendees as consumers looking for a product to satisfy their religious needs (Twitchell 2004: 80-108). They have constructed and branded a form of religion that is uniform, undemanding and palatable for the American religious consumer, one that 
reinforces the 'happy narrative' of the American dream and places Jesus in a kind of megachurch Disneyland, where fact and fiction blur, but where there is always a happy ending and all is well, protected, secure for middle class America in its way of life. Rather than inculcating Christian habits based in a distinct set of beliefs and values, it is suggested that megachurches have actively participated in the commodification of religion (James 2013: 27). It has also been suggested that this criticism can be targeted at other megachurches around the world (Yip 2015). This is a powerful critique and one that deserves to be taken seriously. But it needs to be observed that there are different types of megachurch, for example in relation to migrant megachurches in Europe. Even in America, the picture is not exactly uniform and the Black church stands out as somewhat different from this consumerist model in some respects, if not others.

There is still a religious and cultural divide in America today. While culturally diverse congregations do exist, on the whole it is still the case that Sunday morning is the most racially divided time of the week in American society. Black megachurches exist throughout the USA and provide an interesting case in terms of a learning community. So far, I have tended to look at education in terms of individual education and this is something that continues throughout this chapter. But it needs to be noted that Black megachurches provide a community for individuals to belong to in order to negotiate the racism that continues in America today (Barnes 2015: 112; Tucker-Worgs 2011: 73). Many of these megachurches are located in metropolitan areas, since increased social mobility after the civil rights movement was matched by increased migration to the suburbs (Tucker-Worgs 2011: 45). In all these locations, they provide alternative communities where members develop knowledge and skills, as well as the strategies to cope and thrive in the context of America today. Their educational traditions have roots in the 'self-help legacy' of segregation with many schools emerging from the basements of Black churches (Barnes 2010: $5^{-6}$ ). When this is translated into Black megachurches today it means that these communities are committed to the socio-economic uplift of Black people in which education, both formal and informal, is understood as the key factor in social transformation alongside political and community engagement (Tucker-Worgs 2011: 35-39, 103-132). Of the megachurches studied by Barnes approximately fifty percent of them sponsored Day Schools, private academies as well as youth and adult educational programmes, including health education, for example with regard to HIV/Aids (Barnes 2013). This is in response to poor educational provision in the urban areas associated with poverty and lack of resources (2010: 26). Similar to other megachurches, their size means greater economic and human resources, which in turn translates into a greater number of 
cafeteria-style programmes (Tucker-Worgs 2011: 22). Barnes estimates that the average Black megachurch sponsors at least forty programmes at any given time, thus providing educational opportunities at a variety of levels including computer literacy and social advocacy (2010: 28). These programmes develop especially when the church sermons tend to be practically-orientated ones (2010: 31). Barnes also observes that where large Black churches have embraced a liberationist agenda, then they tend foster education-related programmes (2010: 132). For Hinton (2011), Black megachurches offer a primary curriculum via worship, especially preaching and prayer, and a secondary curriculum via praxis, or prayer-in-action.

Another example of how megachurches as communities have provide institutional learning environments is the immigrant-led megachurches in the global north, especially western Europe (Athyal 2015:34-35). The most obvious example that can be identified is Kingsway International Christian Centre (London and Kent), often referred to as KICC (Asanoah-Gyadu 2012; Cartledge and Davies 2014). This church is largely populated by West Africans, especially Nigerians and Ghaianians, but it also contains some members from the Caribbean. This church provides an alternative community for migrant Africans, one where they can feel at home while away from home. It is one in which their own cultural values are understood, appreciated and honoured. But it is also one in which the differences between the old culture and the new culture can be negotiated with the help of fellow travellers. These fellow travellers offer knowledge and insights on how to adapt to the new cultural environment, providing guides and interpreters for the journey. It is often the case that these largely migrant populated churches also provide technical support to assist their members with immigration and visa issues, as well as advice about employment and education. In this way, these types of migrant oriented megachurches facilitate the socialisation of 'culturally other' individuals into a western context via the mediation of those who have become third-culture individuals, managing to maintain a hybrid existence: successfully adapting while also remaining culturally rooted in their African heritage (Cartledge et al, 2019: 190-199, 203-205, 308-311). As learning experiences go, this is surely one of the most significant ones and it is often overlooked. It is facilitated by a community that is in its very ethos a megachurch educational institution.

\section{4 Characteristics, Evaluation and Future Trajectories}

In this section, the study aims to summarise some key characteristics before suggesting points of evaluation and possible future trajectories for megachurches globally. 


\subsection{Key Characteristics}

It is important to remember that megachurches as educational institutions are very much like other types of congregations insofar as learning occurs in the usual ways of Sunday worship, small group experiences and individualised attention. Where megachurches differ quite considerably is the way in which information and knowledge is packaged for mass consumption, as well as the sheer range of courses and opportunities for learning to occur. There is an economy of scale that influences everything and this includes learning support, provided that individuals adapt to the mass production of everything and can find their own way into it and benefit from what is on offer. In this manner, it could be said that the educational processes that are offered are not formal in the sense of being accredited but they can be very well managed and delivered to a very high standard. This must be one of the attractions of belonging to a megachurch, namely the very professional delivery component of their events and courses. Combined with the worship experience and small group activities, these opportunities offer an overall package of formation that develops conceptual knowledge, hands-on experience, emotional and social intelligence, as well as an embodied form of spirituality. They also provide alternative communities that function as social enclaves against wider culture, but which resource their members with knowledge, skills and support to engage creatively and successfully as wider citizens.

\subsection{Evaluation}

There are a number of strengths that can be noted regarding the nature of education provided for members of a megachurch. First, they demand a high level of observation from the members. If members attend an event, the chances are that they will be watching others operate for the most part, somewhat similar to a concert. While this can create a passive sense of participation, the strength of this expectation is that often what is modelled are highly skilled performances, whether that is in terms of speaking, music, technical expertise or organisational skill. Second, having picked up a serious amount of tacit knowledge through intense observation members can be funnelled into service streams via ministry events that allow them to see the range of opportunities provided for them to serve others. The range of opportunities to serve others can be staggering in scope and number and thus individuals can learn a range of skills and aptitudes by 'having a go' and 'learning by doing', often with mentor support along the way (Barnes 2010: 18). Skills acquired over time through these different ministry opportunities can be subsequently transferred to other domains, thus enhancing the person's ability to find new employment or develop their existing skill set for the purpose of work or other kinds of volunteering, which would have been previously closed to them. Third, it is also the 
case that many ministry opportunities require close working relationships with other people. This means that these opportunities require inter-personal skills, sometimes at very high levels with demanding and vulnerable people. These skills can be personally beneficial, by developing emotional intelligence, but also contributing to family dynamics at home and work dynamics elsewhere.

Megachurches are not perfect institutions and there are weaknesses with them as identified in the literature. In terms of educational weaknesses, there are a number. First, these types of churches, while containing intelligent people from all walks of life, appear to communicate a form of Christianity that is at times simplistic and naïve. Once again, this is not the case with all churches, but it is a sufficiently supported characteristic to be noted as a weakness. This means that the messages that are preached and the material that is produced for discussion can be intellectually undemanding. This has been viewed as a misperception by Thumma and Travis (2007: 91-117), but from the perspective of an academic theologian this perception appears to have sufficient support when considered across the whole spectrum of megachurches. The discussion of this idea by Thumma and Travis (2007) does not really deal with the intellectual side of the criticism but rather focuses on issues around church growth, biblical orthodoxy, aesthetics, the nature of the liturgy, homiletical styles, and theological beliefs, which relate to the question of the intellect but they are not the same thing. From an analysis of megachurch discourse it could be suggested that, by and large, the discourse does not deal with the complex and demanding questions in society requiring an informed and thoughtful response. Second, the information that is communicated is very often out of touch with the best scholarship associated with the sector. Increasingly, there is a vibrant community of Pentecostal and Charismatic scholars from around the world writing on various subjects pertinent to church life, but it is rare to find megachurch pastors who are connected to this scholarly stream. Instead, they appear to recycle ideas from within their own networks, often framed within an anti-intellectualist cordon. Third, the educational material that is produced, while being high quality in form, has a mass-produced character to it that feels as though any thinking outside the tramlines will be met with robust steering back into set ways of thinking. It is aimed at processing the numbers and this means that individual learning needs are overlooked because the mass processing of courses and programmes drives the whole educational venture. The disadvantage of being part of such a massive institutional structure is that it is easy to lose one's own educational trajectory amid the mass-produced world of megachurch culture. 


\subsection{Future Trajectories?}

What will happen in the future as far as megachurch educational culture is concerned? Sadly, it appears that this culture will continue to function at a shallow intellectual level, because the consumerist mentality and drive for numbers is so embedded in it, especially in the USA. The programmes will proliferate and be refreshed over time, somewhat like products on a supermarket shelf. They have a 'shelf-life' and will be replaced once consumer demand has waned, so in order to keep up the numbers new products will be created, marketed and consumed. Some may develop greater intellectual rigour and there are examples of theology conferences being developed to connect with scholars in the field. Some may also find ways of engaging critically with cultural issues, thus developing associate organisations that position themselves in a constructive yet critical posture in relation to wider society. Many megachurches are already using the Internet to their advantage. In some cases, they have set up what have been called 'Internet campuses', where there are virtual churches as part of the megachurch provision (Thumma and Travis 2007: 186). Research on megachurches needs to keep up with these developments by evaluating how they communicate their beliefs and values on the Internet and among virtual communities in particular (Asamoah-Gyadu 2007; Campbell and Wallace 2015; Hackett 2009; Martin et al. 2011). Going forward, this aspect of megachurch worship will develop at a rapid pace because of technological advances. What would be really exciting is for a number of megachurches from around the world to collaborate on an event at which they expose themselves to some of the leading international megachurch scholars. These scholars would be able to offer constructive and critical feedback on their educational practices in order to help them to reflect on what it is that they do and how they can improve their activities for the benefit of their members and wider society.

\section{5}

\section{Conclusion}

By and large, there has not been a full description and assessment of educational practices found among megachurches in the literature. Therefore, given this lacuna, the strategy of this study has been to consider how learning can be understood when one looks at the life and work of megachurches in general terms. It is important to consider learning holistically not just in the light of what might be considered structured events for learning, which would have limited my analysis to specific courses, such as the Alpha course produced by 
Holy Trinity Church, Brompton and distributed to over forty countries around the world (Cartledge et al., 2019: 130-135, Heard 2009; Hunt 2004). These courses are important, but they only really make sense when they are placed within a wider narrative framework, which provides the context in which such courses exist and from out of which they function. This study has not attempted to sketch all the formally accredited educational programmes that can be found among megachurches because most learning occurs as part of the general life of these churches and necessarily so. What is significant about these findings is the fact that megachurches are both similar to congregations of smaller size in that learning exists in the same kind of way as other congregations, but that they are different insofar as their size offers a greater range of opportunities for participation. They are also different to smaller congregations because of the need for high quality productions and performances, without which the numbers would diminish. Thus, the modelling of certain knowledge and skills becomes an important factor in the overall learning environment sustained by the institution of a megachurch over time. In certain settings, they provide a large alternative community that helps inculcate values and practices at a communal level that sustains groups under adverse social and cultural conditions, such as those existing for migrant communities. This learning support is crucial and cannot be underestimated in its value to the individuals and communities concerned. In this regard megachurches as educational institutions play a significant role in the relationship of religion, and especially Pentecostal and Charismatic Christianity, to wider society.

\section{References}

Asamoah-Gyadu, J.K. 2007. "Get on the Internet!' Says the LORD: Religion, Cyberspace and Christianity in Contemporary Africa." Studies in World Christianity. 13:3, $225^{-242 .}$

Asamoah-Gyadu, J.K. 2012. "To the Ends of the Earth': Mission, Migration and the Impact of African-led Pentecostal Churches in the European Diaspora." Mission Studies. 29:1, 23-44.

Athyal, J.M. 2015. "Southern Christianity: Key Considerations and Characteristics." In J.D. James, ed, A Moving Faith: Mega Churches Go South. New York: Sage, 21-40.

Barnes, S.L. 2010. Black Megachurch Culture: Models for Education and Empowerment. New York: Peter Lang.

Barnes, S.L. 2013. Live Long and Prosper: How Black Megachurches Address HIV/AIDS and Poverty in the Age of Prosperity Theology. New York: Fordham University Press. 
Barnes, S.L. 2015. "To Educate, Equip, and Empower: Black Church Sponsorship of Tutoring of Literary Programs." Review of Religious Research. 57:1, 111-129.

Bowler, K. 2013. Blessed: A History of the American Prosperity Gospel. New York: Oxford University Press.

Burns, L. 2017. “Afterword: Hillsong Church Response." In T. Riches and T. Walker, eds, The Hillsong Movement Examined: You Call Me Out Upon the Waters. New York: Palgrave Macmillan, 271-273.

Campbell, A.D. and Wallace, G. 2015. "Black Megachurch Websites: An Assessment of Health Content for Congregations and Communities." Health Communication. 30:6, $557-565$.

Carney, C.R. 2012. "Lakewood Church and the Roots of the Megachurch Movement in the South." Southern Quarterly. 50:1, 61-78.

Cartledge, M.J. and Davies, A. 2014. "A Megachurch in a Megacity: A Study of Cyberspace Representation." PentecoStudies. 13:1, 58-79.

Cartledge, M.J., Dunlop, S.L.B., Buckingham, H. and Bremner, S. 2019. Megachurches and Social Engagement: Public Theology in Practice. Leiden. Brill.

Chaves, M. 2004. Congregations in America. Cambridge, MA: Harvard University Press.

Everist, N.C. 2002. The Church as a Learning Community: A Comprehensive Guide to Christian Education. Nashville, TN: Abingdon.

Fulcher, J. and Scott, J. 2003. Sociology, 2nd edn. Oxford: Oxford University Press.

Hackett, R.I.J. 2009. “The New Virtual (Inter)Face of African Pentecostalism.” Sociology. 46:6, 496-503.

Heard, J. 2009. Inside Alpha: Explorations in Evangelism. Milton Keynes: Paternoster.

Hermans, C.A.M. 2003. Participatory Learning: Religious Education in a Globalizing Society. Leiden: Brill.

Hinton, M.D. 2009. "Back to the Future: Re-appropriating Religion Education - A Case Study Using the Black Church." Religious Education. 104:1, 18-37.

Hinton, M.D. 2011. The Commercial Church: Black Churches and the New Religious Marketplace in America. Lanham, MD: Lexington Books.

Hunt, S. 2004. The Alpha Enterprise: Evangelism in a Post-Christian Era. Aldershot: Ashgate.

Isaac, P.E. 2012. "Expanding the Boundaries of Adult Religious Education." New Directions for Adult and Continuing Education. 133, 83-87.

James, A.B. 2013. "Rehabilitating Willow Creek: Megachurches, De Certeau, and the Tactics of Navigating Consumer Culture." Christian Scholar Review. 43:1, 21-39.

Jordan, S. 2005. "Organizational Studies Strand - Worship and Action." In H. Cameron, P. Richter, D. Davies and F. Ward, eds, Studying Local Churches: A Handbook. London: SCM Press, 113-122.

Kay, W.K. 2004. “Pentecostal Education.” Journal of Beliefs \& Values. 25:2, 229-239. 
Klaver, M. 2015. "Pentecostal Pastorpreneurs and the Global Circulation of Authoritative Aesthetic Styles." Culture and Religion. 16:2, 146-159.

Martin, P.P. and Bowles, T.A., Adkins, L. and M.T. Leach. 2011. "Black Mega-Churches in the Internet Age: Exploring Theological Teachings and Social Outreach Efforts." Journal of African American Studies. 15:2, 155-176.

Mercer, J.A. 2006. “Transformational Adult Learning in Congregations." Journal of Adult Theological Education. 3:2, 163-178.

Pazmiño, R.W. 2008. Foundational Issues in Christian Education: An Introduction in Evangelical Perspective. Grand Rapids: Baker Academic.

Sinitiere, P.L. 2015. Salvation with a Smile: Joel Osteen, Lakewood Church \& American Christianity. New York: New York University Press.

Soon, I. 2017. "A Comparison of the Religious and Ethnic Ethos of Hillsong College with Paul the Apostle." In T. Riches and T. Walker, eds, The Hillsong Movement Examined: You Call Me Out Upon the Waters. New York: Palgrave Macmillan, 107-124.

Thumma, S. and Travis, D. 2007. Beyond Megachurch Myths: What We Can Learn from America's Largest Churches. San Francisco: Jossey-Bass.

Tucker-Worgs, T. 2011. The Black Mega-Church: Theology, Gender, and the Politics of Public Engagement. Waco, TX: Baylor University Press.

Twitchell, J.B. 2004. Branded Nation: The Marketing of Megachurch, College Inc., and Museumworld. New York: Simon and Schuster Paperbacks.

Vermeer, P. 2015. "Church Growth and Appealing Sermons: A Case Study of a Dutch Megachurch.” Journal of Empirical Theology. 28:1, 1-22.

Von der Ruhr, M. and Daniels, J.P. 2012. "Subsidizing Religious Participation Through Groups: A Model of the 'Megachurch' Strategy for Growth." Review of Religious Research. 53:4, 471-491.

Wade, M. and Hynes, M. 2013. "Worshipping Bodies: Affective Labour in the Hillsong Church." Geographical Research. 51:2, 173-179.

Yip, J. 2015. "Marketing the Sacred: The Case of Hillsong Church, Australia." In J.D. James, ed, A Moving Faith: Mega Churches Go South. New York: Sage, 106-126. 